\title{
Beyond the Flexibility/Security Trade-Off: Reconciling Confident Consumers with Insecure Workers
}

\section{Colin Crouch}

\section{Article by an MPIfG researcher}

Colin Crouch: Beyond the Flexibility/Security Trade-off: Reconciling Confident Consumers with Insecure Workers. In: British Journal of Industrial Relations 50(1), 1-22 (2012). Wiley-Blackwell

The original publication is available at the publisher's web site: http://dx.doi.org/10.1111/j.1467-8543.2010.00825.x

\begin{abstract}
The article proposes an analysis of labour markets and related social policy that corrects the supply-side emphasis that has dominated economic policy since the decline of Keynesian approaches in the late 1970s. It starts from a potential tension between the apparent need of economies for both flexible workers and confident consumers. This can be resolved through three different approaches: separating insecure workers from secure consumers, separating consumption from labour incomes, and integrating flexibility and security within the labour market itself. These approaches are played out across four different contexts: place, time, externalizing problems on to minorities within a given community, internalizing problems within the community. Up to 19 different public policies and corporate practices are identified, occupying different positions on the framework. These go considerably beyond the issues of industrial relations institutions and related social policy that are the normal focus of labour market studies.
\end{abstract}

\section{Introduction}

Many discussions of labour market and social policy start from an assumption of tension between the market and demands for protection from its insecurities: welfare, usually the welfare state, 'against' markets. This is seen very prominently in the current preoccupation with a tension between 'flexibility' and 'security' in European policy debates (Council of Europe 2005; European Commission 2005, 2006, 2007a; OECD 1994). The search for policy combinations that will optimize both flexibility and security, known in European discussions as 'flexicurity', demonstrates that constructive and positive compromises can be envisaged between these two forces (European Commission 2007b; Jørgensen and Madsen 2007; Klammer and Tillmann

Colin Crouch is at the University of Warwick. 
2002; Muffels et al. 2008b; Wilthagen and Tros 2004). They are, however, usually seen as compromises. At least among policy makers, there is a strong assumption that markets would be most efficient if they were not troubled by these demands for security. This approach draws much from the so-called 'supply-side revolution' in economics. Beginning as the revolt against taxation from the US centre-right known popularly as 'Reagenomics', in economic writing this was a more general concern for looking at the conditions of labour supply, replacing the earlier concern of Keynesian policies with levels of demand in the economy (Canto et al. 1983; Roberts 1984). But concentration on the supply side has drawn attention away from the fundamental fact that an economy needs both supply and demand. To the extent that labour incomes are an important constituent of demand, and, to the extent that consumer confidence is dependent on workers' confidence in the continuity of their income, the tension between flexibility and security may not only be one between the market and the welfare state, but a condition of the operation of markets themselves.

The purpose of this article is to work out the implications of this simple observation for the study of labour market policies. Several important issues are raised. First, the italicization of 'to the extent that' above draws our attention to the possibility that work income may not necessarily be the main source of demand. Indeed, for most of human history, extensive demand was concentrated on luxury products for elite minorities. The mass of the people existed at a subsistence level. This remains the case in large areas of the world today, which in the global economy are trading with countries where employment income occupies a very different position in stimulating demand. The industrial revolution brought an expansion of mass goods, but initially of low value-added products. The mutual fuelling of growth in both mass demand and mass supply dates back only as far as the Fordist revolution in mass-production methods of the early twentieth century, limited initially to the USA and, later, parts of Europe. Even that, which seemed to constitute a pure market solution to the problem, was contingent on economic conjuncture and did not offer long-term security to mass workers; development of the Fordist system was followed by the economic collapse of the 1930s. It was as a response to that collapse and then to the Second World War that serious policy making linking labour security, consumer confidence and economic growth really dates. Contemporary debates about the tension between flexibility and security therefore need to be set in a broader context, not just of policies and practices, but also of time and place, if we are to understand them fully.

Second, by starting from this perspective, analysis does not immediately turn to the state as the necessary locus of any protections against market uncertainty, but is open to a wide range of institutional possibilities. Examination of different ways in which supply and demand are related to each other provides a distinctive route to the study of different forms of popular economy, or Volkswirtschaft - those aspects of economic life that concern the earnings and expenditure of the mass of the population. Such 
a study includes that of labour and social policy regimes, but seeks to go further. The object of research becomes a range of policies of public and private actors, as well as well practices which, while not consciously constructed as policies, have an impact on life that can be as strong as explicit policy.

The approach also provides an added perspective on the important literature on 'new social risks' (Bonoli 2007; Schmid 2006, 2008; Taylor-Gooby 2004), which has itself been a major intellectual base for flexicurity policies. This literature sees a move away from the risks of threatened income loss (unemployment, sickness, old age) that motivated social policy from the late nineteenth to mid-twentieth centuries to a new set of conditions more characteristic of early twenty-first-century life: population ageing and associated care problems; the balance of family life and female employment; risks that one's educational qualifications will not facilitate employability. These are important issues, and they have profound implications for economic life. One must, however, avoid a tendency to focus solely on explicit social policy, as the list of new social risks may lead one to do. The agenda of risk is more extensive, and ways of coping with it extend further - including of ways of 'dumping' risk on some people rather than others.

This article tries to establish a framework for the analysis of different ways in which the puzzle can be addressed in policy and practice. It does not report research findings, but establishes the parameters for a research programme. The puzzle is conceived heuristically: those engaged in tackling it do not necessarily conceive it in this way; it is not a historical process. It does, however, provide a lens through which it is useful to observe structures and changes. The basic empirical elements of the approach will also be found in Crouch (2010); what is new in the present article is the attempt to place these within a theoretical framework that can accommodate further empirical cases and from which hypotheses might be generated to account for forms taken by different approaches to the puzzle in different situations.

It might be suspected that such a starting point would lead to a functionalist account of social policy, or at least one that considers shared interests of capital and labour in the development of social policy (e.g. Swenson 2002). This is not the case. It will be seen in the following discussion that there is considerable scope for conflict among rival interests and for suboptimal solutions resulting from these. The reconciliation of consumer confidence and labour insecurity is treated throughout as a puzzle that is not easily resolved; and different interests play their rival strategies in the search for resolution.

\section{Establishing the framework}

We can identify three different fundamental approaches to the puzzle. The first (I) does so by separating populations into those who bear the risk of labour-market flexibility and those who have the security to consume.

(C) Blackwell Publishing Ltd/London School of Economics 2010. 
The second (II) separates capacity to consume from the rewards of labour without separating the people who consume from those who provide labour, but by differentiating these functions within the same persons. The third (III) seeks a resolution within the labour market relationship itself, somehow reconciling consumption confidence and labour flexibility.

These approaches will normally be observed within particular societies at particular periods of time, and it is common for research to isolate its cases in place and time in this way. This is, however, misleading, as different places and times relate to each other. The present scheme will therefore consider three different contexts, corresponding roughly to the three fundamental adverbial forms: place, time and manner. The issue of place reminds us that it should not be assumed that the central puzzle has to be resolved within one geographically defined society or jurisdiction (treated here for simplicity as nation-states). This is especially important in a global economy with much production organized by transnational corporations. We must therefore ask (A) where, literally and geographically, confidence and insecurity are distributed. Turning next to time, we encounter the scope that exists for risks being pushed into the future in order to reduce uncertainty today; and for today to gain security from the products of past insecurity: the question (B) when. Finally, considering the manner in which the central puzzle is confronted within specific places and times (the question how) brings us to the normal field of policy research. While there is an enormous diversity in potential answers to the 'how?' question, we shall here simplify it into a choice between two extremes: (C) what we shall call 'internal externalizing' contexts - in which burdens are 'dumped' on specific groups within the society, just as use of the place and time dimensions allows dumping on people in other jurisdictions or living at other periods; and (D) 'internalizing' or universal contexts - in which burdens are, at least in principle, shared evenly among all members of a specific society. Thus, two of the contexts (time and place) involve the society of reference externalizing uncertainty on to outsiders; two (both of manner) internalize within the society, but one of these externalizes within itself.

Combining the three approaches and the four contexts gives us the potential analytical frame shown in Table 1 . Two of its boxes remain logically empty. Segregation by place separates different persons, and is therefore incompatible with universalism; box I.D is always empty. Integration of security and flexibility is not possible across different spaces, so box III.A is also empty. There are therefore potentially 10 combinations of different approaches and contexts. The numbered items within the boxes in the table refer to the examples of policies and practices in the following discussion. It must be stressed that these are only empirical examples; the list tries to be extensive, but it is not exhaustive, and the importance of the examples varies considerably. It is the analytical frame that claims to be exhaustive, in the sense that any approach to resolving the central puzzle will be able to be located in one or more of these boxes. 


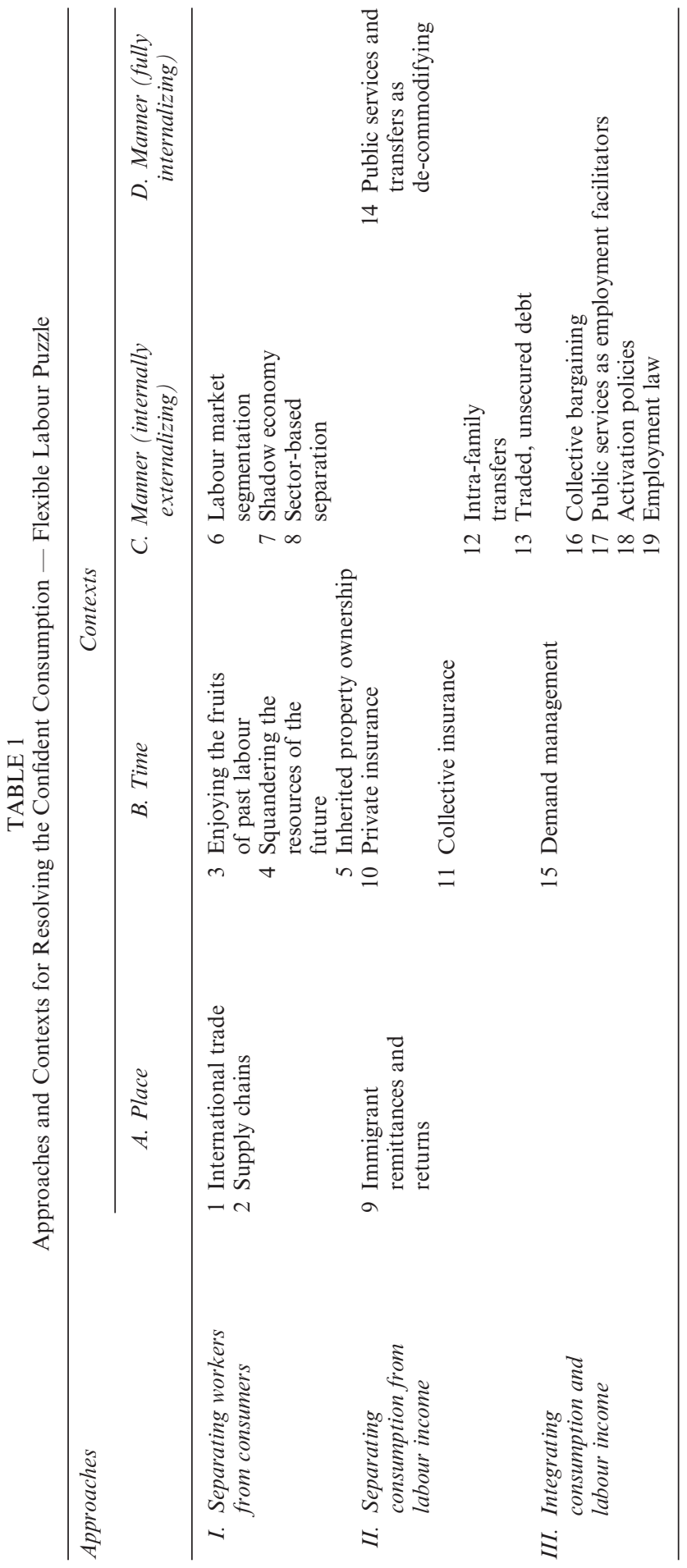




\section{The Separation of Consumers from Workers}

\section{I.A Separation by place}

The most fundamental means for separating consumers and workers into two non-overlapping groups, such that the confidence of the former is in no way affected by the vulnerability of the latter, uses the international division of labour. This basic geography needs to be established before we treat countries as equal 'cases', expected to respond in the same way to the same policies. There are two different but inter-related means: international trading patterns and supply chain organization.

1. International trade. In a world of sovereign national jurisdictions, the central puzzle can be resolved if confident consumers live in some locations and insecure, highly flexible workers in others. In an oversimplified theoretical case, we can assume that there are two kinds of locations: those that export production by insecure workers, who do not themselves consume much, and those where confident consumers, whose own employment is in sectors not vulnerable to the fluctuations of production, import the products of the former.

The former case covers countries having two characteristics: at least temporary restraints on domestic mass consumption, and success in producing exportable goods. A regime of this type was dominant in the Bonn Republic during the early years of post-war recovery in the 1940s and 1950s. German workers were very poor, but the Second World War victor countries and various neutrals were on a different economic path and provided mass markets for German goods. Today, many developing countries in the Far East, and also in central and eastern Europe, are making major use of this resolution of the puzzle, though it has recently encountered a crisis in several of the latter, which are running serious trade deficits while not having developed an alternative to export dependency.

The other side of this coin is the existence of other countries that import the products of the exporting countries, and who themselves depend on domestic production and consumption (probably mainly of services), debt or other devices to finance mass consumption. These are better able to protect their workers' consumption, as their labour demand is less elastic: a decline in demand for goods will mainly affect labour in exporting countries. Such countries - major examples are the UK and USA - will, however, be running long-term trade deficits. This is therefore a sustainable approach only for financially powerful countries, whose debts others find it advantageous to hold; collapse of confidence in their debts threatens the viability of the approach.

2. Supply chains. A second way in which the international division of labour comes into play is through the development of international internal markets, sub-contracting and supply chains organized by the managements of transnational corporations. These usually offer explicit or implicit guarantees of employment and/or stable incomes to some sections of the work force, located in certain parts of the world, but not to others. The protection 
offered to insiders is partly dependent on outsiders bearing the brunt of any instability produced by market fluctuations. This is very commonly the case with clothing and textiles, where most production is carried on in China and other parts of Asia, at very low wage levels and under low conditions of labour security, while corporate headquarters and final product markets are to be found in wealthy countries (Miller 2009). As with the international trade case, employment (and therefore mass consumption) remains relatively stable in the privileged locations, for whom there is a response to the central puzzle. There is not, however, a response for the countries at the unstable end of the supply chain.

\section{B Separation over time}

The time dimension is relevant to the division of populations into consumers and workers if one envisages divisions over a sufficiently long period that there is little or no overlap between the two.

3. Enjoying the fruits of past labour. Consumption standards at time $t$ may be enhanced by the use of assets and resources constructed at time $t-1$, whose construction may have been possible only because workers at the earlier time were not compensated to an extent that enabled them to consume. This was a common feature of the accumulation of capital and infrastructure, but also of institutions, in today's wealthy societies, even though the process took various different forms (Rostow 1965). This makes it easier for their populations to consume at high levels now. Labour and social policy research usually takes such matters for granted, but in comparing countries with very different historical backgrounds, it can be highly relevant. This is especially so when considering countries trying to develop very rapidly now, requiring populations to forego current consumption in ways that are not necessary for people in already wealthy countries. Like the issues discussed under I.A, it produces cross-national differences that need to be considered in comparative studies.

4. Squandering the resources of the future. The other side of this coin is when a generation at time $t$ consumes at high levels because it is able to ignore externalities produced by this consumption that will affect negatively a generation living at time $t+1$. The latter will presumably have to work harder with poorer consumption opportunities. In this way environmental damage and man-made climate change - major examples of how this can operate can be incorporated in the study of labour and social policy.

5. Inherited property ownership. A major means for dividing consumption opportunities from work obligations is the existence of large wealth holdings, extracted from labour incomes at time $t-1$ and giving consumption opportunities without a need to work for an inheritor generation at time $t$. Consumption at time $t$ is then heavily concentrated among non-working elites, while the rest of society provides flexible, poorly rewarded labour, hardly able to afford to consume beyond subsistence levels. This is the solution to the central puzzle that has predominated for most of human history and across most of the world, unless and until mass domestic 
consumer markets develop. As a regime, it has two principal disadvantages. First, without mass markets, there are severe limits to possibilities for economic growth; consumption growth is concentrated in luxury goods. Second, it depends on the economic, social and political exclusion of the mass of the population, which often requires an extensive apparatus of suppression.

\section{I.C Separating types of person at the same place and time}

Inherited property of the kind discussed under 5 above obviously has contemporary implications, as well as those over time. In most societies, small wealthy minorities distinguish themselves from their contemporaries by their capacity to consume without having to work. Therefore, the box containing point 5 extends into I.C territory. Many other factors also provide scope for a segregation of people into consumers and workers within one society, but concentrating consumption among majorities, who do themselves work but with strong expectations of security and with income levels that give scope for spending. The excluded minority lacks security, but since its incomes are low, this does not have important implications for consumption.

6. Labour market segmentation through demographic characteristics. As noted above in connection with international differences in levels of security experienced by workers in different parts of the world, managements of large corporations usually develop internal labour markets, sub-contracting and supply chains offering different levels of exposure to risk. The same processes occur within societies, partly through supply chains, but also through other factors that result in different terms and conditions being offered to different kinds of person. Managements make use of contracts of different types and duration, including labour-only sub-contracting, to distinguish between secure, well-paid core work forces and insecure, usually low-paid ones. While among employees, there tends to be a positive correlation between security and income, as employers can indicate the value of an individual or category of worker through both, among people on self-employment contracts, the opposite can be the case. Highly paid contractors (such as consultants) may earn high fees but have no security, deriving their consumer confidence from the strength of their market position. Low-paid self-employed, on the other hand, have neither contractual nor financial security.

Various demographic characteristics become an important basis for allocating people among these categories. The main examples are:

6.i Family background. Weak access to labour market opportunities can be caused by inequalities of access to marketable resources, such as education, resulting from circumstances in family of upbringing.

6.ii Ethnicity. Members of ethnic or cultural minorities may enjoy lower formal citizenship rights, excluding them from various forms of labour security. Illegal immigrants are an important example in many contemporary advanced societies. Alternatively, discrimination takes place informally, through general social exclusion, or through weaker access to markets as in 6.i. 
6.iii Gender. Their role in childbearing has presented many reasons for relegating women to less secure labour-market positions, ranging from formal discrimination against their access to employment rights to consideration of their employment as less important to that of the 'breadwinner' males with whom they are assumed to live. In most societies, women constitute a majority rather than a minority, but they are usually a minority of the remunerated work force.

6.iv Age. Both extremes of the age range can be exposed to low security and low wages. The young may have difficulties accessing strong positions or rights, which are often based on tenure in a job, or, like women, they may be considered to have access to family resources to support their consumption. The old may be regarded as providing less efficient labour, or again be considered to have access to family support, and where there are pensions, be regarded as not needing labour income to support their consumption.

7. Shadow economy. Most studies of labour protection regimes and flexibility usually consider formal rules and assume that these are effectively implemented. In doing so, they miss both part of the reality of labour market regulation and important numbers of employed persons, as the shadow economy does not appear in any statistics (Burroni and Crouch 2008; Schneider 2007). It is important that research takes full account of the size and place of the shadow economy, because it forms a major device for separating consumers from producers, and certain producers from others. In developing economies, illegal work and firms without a legal existence are the norm. Within Europe, there are important concentrations of the shadow economy in the south, and, in particular, the former state socialist economies. But it is a part of the reality in all. The shadow economy overlaps with, or can be an aspect of, discrimination against illegal immigrants, but it is not limited to their case.

8. Sector-based separation. Different kinds of economic activity may offer different degrees of protection from insecurity and different levels of income. These differences may result from government protectionist strategies towards favoured sectors or from market processes. Sometimes public employees enjoy particular protection from economic uncertainty. A different form of stability of employment chances in the face of market fluctuations can occur where large numbers of firms, particularly but not solely small and medium-sized enterprises (SMEs), in related areas of activity, cluster within geographical areas or industrial districts. Both the craft sector of the Italian economy (Beccattini 2000) and the Californian information technology industry (Kenney 2000) provide examples of this phenomenon. Workers in such situations perceive that they have a diversity of employment opportunities available to them within a geographical range and within social networks. The fragility of individual small firms does not therefore necessarily threaten employment and income levels. Of course, districts and other 
clustered activities move from being particularly resilient to being particularly brittle when there is a collapse of the whole sector in which the area is specialising, as this frequently leaves few employment opportunities, leading to a crisis of confidence and a decline in purchasing power. They are, however, a useful example of how individuals may find forms of security apart from social policy.

\section{The Separation of Consumption from Labour Income}

II.A There is a theoretical possibility that people might practise their insecure labour activities in one jurisdiction but consume in another, the former economy not being disturbed by the interruptions to consumption that are involved. This is, in practice, likely to be only a very minor solution to the central puzzle, but it is worth considering for completeness.

9. Immigrant remittances and returns. Immigrant workers may provide this kind of place flexibility in two ways. First, they send a part of their labour earnings home to their families. For some economies (e.g. the Philippines), these payments can form a major component of national income. If the workers lose their jobs, the economy of the host country does not bear so much loss from the decline in their consumption, as this is concentrated in their country of origin. Somewhat similarly, when immigrant workers find their labour insecurity intolerable, they may return home, again sparing the host country the costs of unemployment support.

\section{II.B With II.C and II.D separation over time and within time}

Individuals can sometimes separate their consumption from their labour income by making use of time, though as the time horizons are short, in practice, it is sometimes difficult to distinguish this from in-time separations, hence the extended boxes across B, C, and, occasionally, D, for some items here.

10. Insurance. In a pure market, the central puzzle posed in this article does not arise. Since participants in such a market have perfect knowledge, and prices adjust marginally and immediately to any change, there are no endogenous shocks. All adjustments are smooth; flexibility does not imply uncertainty of a kind that should damage confidence to consume. There are two problems with this. First, the market is not proof against exogenous shocks, and while the range of exogeneity can in principle be reduced by extending the scope of the market, such things as natural disasters and wars will remain capable of imposing shocks. Second, no one starts from the position of being in a pure market; there are market distortions throughout economies, some caused by public policy interventions, others by inability to achieve perfect knowledge, others again by imperfections in competition. It is possible to resolve this problem within the market through the private insurance principle and the consequent sharing of risk. Apart from major and unpredicted catastrophes, those whose risks are insured can continue to spend without making their own full provision against possible losses. Risk is shared, and the sharing operates primarily across time, as it is over time that the insurance funds are accumulated. 
Important though this model is for many forms of risk, it is not common for the mass of a workforce to insure privately against labour market risk. Such behaviour is vulnerable to three forms of market failure. First, the costs of such insurance would take the poor to very low levels of subsistence, leading them to fail to insure, as they have to rank a small improvement in comforts today over provision for the future. Second, more generally than this, individuals are myopic in relation to likely major economic developments and find it hard to make rational calculations concerning their insurance needs. Third, the classic reasons for breakdown of insurance markets adverse selection and moral hazard - are likely to be a severe problem, particularly for insurance against sickness and unemployment. The main exception to this general under-provision concerns private retirement pensions, though even these tend to be restricted to higher-income groups.

11. Collective insurance. Given that there is a collective interest in resolving the flexibility/security confrontation, and that individuals must be expected to take precautions below the level needed for this collective purpose, this is an area where governments and associations, sometimes individual corporations, have intervened, typically providing insurance-type policies to sustain purchasing power under conditions of instability or disappearance of employment income, such as unemployment, sickness and retirement. There is an important difference here between so-called 'Bismarckian' schemes, which enrol certain types of employee in category-based funds, which tend to be exclusionary (category C), and 'Scandinavian', or universal ones that embrace all workers in a society (category D). Today, there are strong trends to convergence between these two once very distinct schemes, as the state underwrites the accounts of increasingly inclusive category schemes while immigrants are often excluded from 'universal' ones. Company-level and employer-managed occupational pension schemes, which are often ignored in studies (but see Shalev 1996), come under category C.

\section{C (and II.D) Separating consumption and work at the same place and time (internally externalizing and occasionally universal)}

12. Intra-family transfers. Studies of social policy and redistribution usually concentrate on relations between markets and state provision, leaving out the activities of the family. While its welfare role was historically considerably reduced by the rise of the welfare state, it remains fundamental for the living standards and security of persons not participating in the labour market, whether because of age, disability, household responsibilities or unemployment. It is also an important channel for inter-generational transfers, for example for housing finance. However, whereas pension and other insurance schemes are in theory capable of balancing security and risk over lengthy periods of time, internal family transfers exercise their trade-offs contemporaneously.

While elements of the role of the family can be seen in most societies, there is considerable diversity. In the case of young people, there is major difference in mean ages for leaving the parental home — ranging from the 


\section{British Journal of Industrial Relations}

early 20s in northwest Europe to over 30 in the southwest (Jurado Guerrero and Naldini 1996). Social norms play a part in determining such differences, but these are sometimes supported by social and fiscal policy. In Germany and several other European societies, the pensions and home ownership being enjoyed (or confidently expected) by older generations is enabling them to sustain the living standards of their adult children who find themselves in the insecure labour market (Kohli 1999; Kohli et al. 2010). These intergenerational transfers offset the conflict between generations that is often predicted, but rarely occurs, between an older generation that enjoyed the postwar welfare state and a younger one coping with the rigours of the neoliberal economy. To some extent, the latter economy is being sustained by the past legacy of a different kind of regime. Since the resource endowments of different families are very unequally distributed, this is a form of contemporaneous separation of consumption from labour income that does not operate universally; it is therefore an instance of II.C.

13. Traded, unsecured debt. Practices developed in financial markets for completely different purposes have also had the effect of separating individuals' consumption behaviour from their labour market income, again to some extent operating over time, but over short intervals. These practices have involved facilitating consumer debt, either backed by collateral that is independent of labour market position or completely unsecured. They evolved in a major way in a number of countries, principally the USA, the UK and Ireland. They required three conditions. The first was a general rise in home ownership funded by mortgages, giving individuals on moderate and even low incomes forms of collateral partly independent of labour market position. The second was the growth of secondary financial markets that enabled the risks associated with housing and other forms of debt (such as credit cards, which were growing during the same period) to be shared among an increasing number of players in the financial markets. The third was a gradual deregulation of financial markets on a global scale, which enabled more and more players and holders of different kinds of funds to enter these markets. Eventually, risks were being shared so widely that collateral requirements on mortgages, credit cards and other forms of debt became nugatory. The sums that people could borrow both rose strongly and - the point that is relevant to our present discussion — became detached from their labour market positions.

The system can be seen as a market-generated functional equivalent of government demand management - a form of 'house price Keynesianism' (Hay et al. 2008), or 'privatized Keynesianism' (Bellofiore and Halevi forthcoming; Crouch 2009). However, whereas under straight Keynesianism (to be considered below), government used its own borrowing to smooth fluctuations in labour income over time by sustaining the level of employment, under privatized Keynesianism, consumption is sustained by separating purchasing power from labour income among individuals, and with no time horizon. Borrowing is undertaken by individuals themselves on the basis of property mortgages or credit card ratings largely divorced from labour market 
situation. The collective goods element in this practice - the maintenance of consumer confidence - has meant that public policy eventually became involved in sustaining it. The model depends on continued housing market buoyancy, and governments may intervene to ensure this situation. This regime is vulnerable to eventual questioning of the value of the risks being traded, as was demonstrated in 2007-2009 in a financial crisis of global scale.

These practices have some relation to the role of property ownership in 6 , discussed above, except that they have been far less exclusionary. It had been a major project of post-World War II conservatives in many countries to promote a 'property-owning democracy', with the hopes of persuading many mass voters that their interests lay with property ownership rather than with their labour power. They therefore encouraged home ownership and investment by mid-income people. The approach may have had some success at the level of political identity, but by itself it could never produce a lower-middle or upper-working class for whom property income was more important than that from labour. However, once the unforeseen association between secondary markets in risk and housing and credit card debt was forged, the project became more realistic as a substantive separation of many people from dependence on an increasingly insecure labour income for their consumer confidence. It became a kind of privatized welfare state. The project never became strictly universal and hence can be listed under II.C, there always being large numbers of people too poor to gain a mortgage or even a credit card. It did, however, reach a long way into the socio-economic hierarchy, and had tendencies towards universalism and II.D.

\section{II.D Separating consumption and work at the same place and time (shared)}

14. Public services and transfers as decommodifying. When public services are funded by taxation and provided free or at very low cost at the point of receipt, they decommodify those services, or remove them from the market. This relieves people of the need to make provision for them out of their labour incomes, reducing any anxiety imposed by labour market flexibility and any negative effect on private consumption. The same applies to social assistance and basic pensions programmes. The macro-economic (as opposed to individual) stabilizing effect of these policies may not have been part of their design, but they are among their consequences. These schemes are normally potentially universally available to members of the society concerned, with the exception of illegal immigrants.

\section{Integrating Consumption and Labour Income}

III.B, with III.C and III.D Integration across time

15. Demand management. The integration of policies and practices so that flexibility and security (or labour insecurity and consumption confidence) operate together is not easy, and usually require conscious collective policy making rather than the incidental consequences that we have observed in many of the other examples considered above. The use of time as a separating 


\section{British Journal of Industrial Relations}

dimension can be important in this, though again it is not easy to distinguish the past from the present or future. It is also not always easy to tell a priori whether policies are operating in an externalizing or internalizing way, though actual research can easily do this.

Under so-called 'Keynesian' demand management, government uses its own spending to boost the economy to avert recession and to cool it during inflation. By damping the fluctuations of the trade cycle over time, it seeks to reduce the degree of insecurity in the labour market. This was the main macro-economic strategy pursued in the USA, the UK and the Nordic countries for the first three decades after World War II. It contained within itself the risk that democratic governments would find it easier to expand demand (increasing employment, creating more services and/or cutting taxes) to ease recessions than to reduce it (increasing unemployment, cutting services and raising taxes) to prevent an economy from over-heating. It was therefore likely to be inflationary, and fell into relative disuse after it was considered to have worsened the inflationary crises of the 1970s, though it has remained in the policy repertoire of many governments. Its effects are felt at the level of the general economy rather than by individual groups, so it can be classed as a universal set of policies, and therefore operates in III.B and III.D.

\section{C and III.D Integration across time}

It is within these last categories that we find most of the institutions usually associated with explicit industrial relations and labour policy. When groups of these are operated together, usually as explicit public policy, we observe what have become known as 'flexicurity' policies, or sometimes the 'investment state'.

16. Collective bargaining. Collective bargaining between trade unions and either individual firms or groups of employers is normally associated with reinforcing labour-market stability of a kind that can support consumer confidence, but at the expense of flexibility. However, because collective bargaining involves negotiation and is capable of operating at a strategic level, it is possible for the participants in bargaining to trade flexibility and security (Burroni and Keune 2009). They sometimes achieve this through encompassing bargaining, where negotiators represent such a large proportion of the labour force that they cannot externalize, at least within their own society (Olson 1982); or when there is a significant role for unions and associations representing the exposed sector of the economy (Traxler 2003; Traxler et al. 2001, 2008). Alternatively, when bargaining takes place at the level of the individual firm, workers' representatives may have to trade the short-term protection of their members' security against possible needs for flexibility if the firm is to survive. This is generally known as concession bargaining.

Whether collective bargaining operates in an externalizing (III.C) or internalizing (III.D) way depends very much on these same differences in how associations are structured and whom they represent. Fully encompassing bargaining can be universal in its impact, but if unions represent certain skill levels, age groups, ethnicities or genders, their impact may combine with that 
of 6 under I.C and protect the security (and therefore the consumption) of insiders at the expense of a flexible labour force of workers with limited rights.

Meanwhile, collective bargaining remains primarily national, while managements in large corporations are operating globally, restricting considerably the scope of bargaining to develop an autonomous approach to the flexibility/security trade-off. There have been some examples of EU-level action and concerted cross-border responses, which, though small in proportion to the overall level of economic activity, may be important harbingers of future developments (Erne 2008).

There is occasionally an extension of the reach of collective bargaining into III.B (i.e. use of a time dimension). Unions may seek to use collective bargaining counter-cyclically, accepting restraint and the priority of competitiveness during periods of rising costs, but seeking to boost consumption through high wages during recessions (as recently attempted by German unions).

17. Public services as employment facilitators. The direct provision of public services - discussed above with reference to the separation of consumption from labour income - has had a secondary, originally accidental consequence that is better considered under the current heading. While under 14 , its decommodifying role in consumption was discussed, we here address its commodifying role in the labour market. Public services offered in kind include a range of care services: child care, sickness care, elderly care. Where these services are provided by the market, they tend to be too expensive for people on modest incomes, so there is under-provision. They are often provided, as in much of southern Europe, within the family, primarily by women. In that case, the provision exists, but not as part of the labour market. Where government provides or subsidizes services, they are still primarily provided by women, but within the labour force, generating jobs, incomes, and therefore purchasing power (Bonoli 2007). Further, other women relieved of family caring roles by the availability of the public services enter other parts of the labour force. This leads to a kind of 'feminomultiplier' of job creation. Within Europe, those economies that provide high levels of publicly funded direct services have higher levels of female and aggregate employment (Esping-Andersen 1999). This has had a number of implications for the flexibility/security trade-off. To the extent that populations live in male/female partnerships, the increase in female participation has brought the stability of two separate employment incomes to households. Given the differences in the sectors in which men and women are likely to work (with women less likely to work in the exposed sectors), the dependence of individual households on individual industries will often be reduced. There is a further element, only partly linked to the gender issue. Not only is publicly subsidized consumption relatively excluded from market fluctuations, but so is employment in the delivery of such services. The larger the population that works in sectors partly protected from market forces in this way, the larger the overall stabilizing impact of public policy.

(C) Blackwell Publishing Ltd/London School of Economics 2010. 
Again, inspection of the full details of schemes is necessary before one can determine whether they are exclusionary or universal. For example, childcare support may be provided on a universal basis or may be available only for those able to afford it from private resources. The role of public employment in providing relatively secure work for many women might operate as an exclusionary device on behalf of privileged public employees, or it might provide a general support to confident consumption throughout an economy.

18. Activation policies. Government programmes for the unemployed are in many countries increasingly being linked to active labour market policy (ALMP) measures (Bonoli 2007). These are a form of publicly supported personal insurance that takes the form of investment in one's own education. However, its future orientation is very short-term, as it is expected to have a pay-off after a few months, so it is rightly considered in the current category. Included here are some Danish and Dutch 'flexicurity' measures (Muffels et al. 2008a; Rogowski 2008). These can be distinguished from simple workfare policies, where workers are given strong negative incentives to take any job that is available; these do not provide support for personal education investment and do not involve state support of individuals' consumption. These policies are potentially universal in coverage, but might also operate in exclusionary ways. Again, the details of policies have to be scrutinized to determine whether they operate as III.C or III.D, but the policy intention is usually for the latter.

19. Employment law. Labour law is another major policy area, which can operate universally or in an exclusionary way dependent on its terms. During at least democratic periods, the main purpose of labour law in most countries has been to protect the rights of employees against employers who are regarded as being prime facie more powerful than they are (Davies and Freedland 2007; Knegt 2008). It has therefore been a force on the security side of the flexibility/security equation. As such, it has come under sustained criticism from economists and others during recent years when increasing employment has been seen to depend on increasing flexibility. The aim of much of this criticism has been to encourage labour law to accept a role in achieving a balance between security and flexibility. This is sometimes expressed in terms of degrees of deregulation, but deregulation nearly always requires some re-regulation, as maintenance of the market order itself requires a framework of rules (Majone 1990). A key development in at least some countries has been the introduction of 'reflexive regulation', or legally induced 'voluntary' regulation to induce reductions in standards of protection, matching attempts in collective bargaining for derogations from sector standards by company-level negotiators. The relationship between labour law and activation policies is often central to flexicurity policies.

\section{Governance}

Different forms of governance are at work among these policies and practices, producing further sources of variation in outcomes. The theory of 
governance has identified a number of key modes: law, government, market, corporate hierarchy, association, network and community, at least one of which will be present within any individual context (Crouch 2006: ch. 5; Hollingsworth and Boyer 1997; Hollingsworth et al. 2002). There is not enough space here to examine the scope for each of these within each of the approaches and contexts discussed, but a few observations are important.

First, once we include practices as well as public policies and market forces as constituting the arena within which the puzzle is resolved, we see the important role that is played by individual large corporations (governance by corporate hierarchy). For example, they are fundamental to the design of international supply chains (2) and within-country segmentation (6), as well as insurance schemes (10 and 11), and collective bargaining (16).

Second, we see that various forms of governance are involved in defining and maintaining the divisions within populations that are necessary for both exclusion through property ownership (5) and segmentation arrangements (6) to endure. Minority elites normally need to have their positions protected in law, buttressed by the power of family (community governance) and the market. Segmentation can be maintained by combinations of virtually every form of governance, from law to community.

Third, sector-based separation (8) is particularly complex. It may emerge from market forces, but governments may seek to stabilize economic activity by protecting industries seen as of particular importance. Workers in these then have a strong expectation of security, while the burden of flexible adjustment is borne by those in other sectors. This was a strategy particularly favoured in France and Italy after World War II. It generates divisions between insiders (in the protected industries) and outsiders (in the nonstrategic industries, usually light manufacturing and sectors dominated by small firms). This kind of government-induced segregation of sectors had been becoming increasingly difficult to maintain, particularly in the European Union, as it breaks many rules of competition law. However, it re-emerged in slightly different form with the 'rescue operations' launched, in particular in the UK and USA, in the face of the 2007-2009 financial crisis to protect firms in the financial sector.

None of these sector-related issues is normally considered to relate to explicit labour market security or social policy, but there can be considerable difference in the demands made on such policy depending on what is happening in relation to them.

Fourth, there is also complexity around the governance of insurance. Market governance clearly dominates private insurance. Collective insurance may be managed by government alone, but in several countries, it is also a major field for associational governance by unions and employers' associations. And many (though a declining number of) individual corporations (corporate hierarchies) organize insurance in the form of pensions for their employees. These collective schemes, like purely private ones, operate over time and within time, and may be either internally externalizing or internally universal. In general, however, associations, and, in particular, government, 
are more likely to deliver universal schemes than the market and corporations, as the latter have no incentives to provide collective cover.

\section{Conclusions: using the framework}

The purpose of the framework presented here is to provide an analytical scheme that can be used in both single-country and comparative studies, with the particular purpose of encouraging research to pay attention to the wider context of explicit social and labour policies, as the role and impact of these latter may be considerably affected by this context, as some of the examples discussed above have hinted. For example, can we examine Danish flexicurity (usually seen as concerning 17-19) without considering the role of collective bargaining and strong trade unions (16), the importance of industrial districts (aspect of 8) and the place of Denmark in global supply chains? Can we consider British labour market changes during the past two decades without examining the role of unsecured debt (13) and the country's ability to sustain an import-oriented economy (1)? Such research would then be further enriched by consideration of patterns of governance, especially in those cases where there is choice and diversity of the modes in operation.

The nationally produced nature of many relevant data, combined with the importance of national social policy and employment law, biases studies of the kind proposed here: nation-states are almost certain to appear as major independent variables, while transnational corporations and (for Europeans) the European Union cut across this level in important ways. One can counter this unintended 'methodological nationalism' by also using the framework to map on it, say, EU policy across all relevant dimensions, including study of how that has changed over time. There would, for example, be a shift away from early (1950s) policies for protecting employment in certain sectors (item 8), primarily agriculture, coal and steel, through the strengthening of workers' protection rights associated particularly with the Delors presidency (items $16,18,19)$, to a more recent concentration on activation policies (18) more or less alone.

At first sight, the three approaches developed in the framework resemble the basic political families of western European history, as used also in the Esping-Andersen (1990) model of welfare states: I: conservatism, dividing populations workforces into categories; II: social-democracy, with its decommodification strategy; and III: liberalism insisting on integration through the market. There is even an indication (in 5 and 12) of a family-oriented form of conservatism, as much research has shown to be necessary to complete the Esping-Andersen account (Ferrera 1996; Naldini 2003). But EspingAndersen's theory is concerned with certain aspects of income-replacement schemes, and does not claim to account for the whole range of social policy, even though it has often been used by subsequent writers to try to do so.

One strength of Esping-Andersen's theory was its historical rootedness, albeit of a somewhat stylized form, in classic class confrontations in the 
construction of industrial society, following the Scandinavian tradition of the study of the role of cleavages in forging the modern world (Korpi 1978, 1983; Rokkan 1999). But this approach tends to become fixed in time. Once the Rokkanian cleavages have done their work by some point in the nineteenth century, societies are set in a path dependence that seems to go on reproducing itself. Is the formation of post-industrial society not producing new cleavages that shift these dependences? Esping-Andersen himself has in recent work (Esping-Andersen 2009) identified female labour-force participation as a major example of a new force that is having such an impact.

The approach proposed in this article enables us to re-examine EspingAndersen's model, focusing on a far wider range of policy areas and allowing for the possible impact of other and later historical forces. Whether or not we would arrive at any grouping of national systems at all, and if so, how it would compare with that of Esping-Andersen's, cannot be determined without empirical research.

A final issue that can be addressed with the framework, but which has been avoided here to reduce complexity, is sustainability. Research in the social and labour field can no longer be carried on in isolation from this. There are two meanings: the sustainability of institutions themselves and the literal meaning of environmental sustainability. Thinking more specifically of the natural environment, we need to pay attention to the fact that strategies that depend very much on expanding international trade are also involved in the export of products from polluting industries.

In terms of institutional sustainability, it would, for example, be useful to compare the overall costs and benefits of different national choices between corporate bailouts and public transfers and services as means of tackling the current crisis. Keynesian demand management was considered to have become unsustainable following the inflationary crises of the 1970s, though it remains an element in the policy armoury of many governments. Even larger questions hang over the sustainability of the housing and consumer credit regime that partly succeeded it.

A less obvious example concerns the fact that, at least in Europe, those economies that provide high levels of publicly funded direct services have higher levels of female and aggregate employment (Esping-Andersen 1999). To the extent that populations live in male/female partnerships, the increase in female participation has brought the stability of two separate employment incomes to households. Given the differences in the sectors in which men and women are likely to work (with women less likely to work in the exposed sectors), the dependence of individual households on individual industries and on the private market will often be reduced. Most important, there is a 'femino-multiplier' at work in women's employment, as the taxation revenues that it creates make possible further public-service provision and more predominantly female employment.

Final version accepted on 25 August 2010.

(C) Blackwell Publishing Ltd/London School of Economics 2010. 


\section{Acknowledgements}

This article has been prepared as part of my work for European Union Framework Programme 7 project 'The Governance of Uncertainty and Sustainability: Tensions and Opportunities' (GUSTO) (grant no. 225301). I am grateful to colleagues within that project for comments on earlier drafts, but the precise approach of this article is not necessarily shared by them.

\section{References}

Beccattini, G. (2000). Il Distretto Industriale. Turin: Rosenberg and Sellier.

Bellofiore, R. and Halevi, J. (forthcoming). 'A Minsky moment? The subprime crisis and the "new" capitalism'. In C. Gnos and L. Rochon (eds), Credit, Money and Macroeconomic Policy: A Post-Keynesian Approach. Cheltenham: Elgar.

Bonoli, G. (2007). 'Time matters: postindustrialization, new social risks, and welfare state adaptation in advanced industrial democracies'. Comparative Political Studies, 40 (5): 495-520.

Burroni, L. and Crouch, C. (2008). 'The territorial governance of the shadow economy'. Environment and Planning C, 26 (2): 455-70.

_ and Keune, M. (2009). Understanding the Multiple Sources of and Relationships between Flexibility and Security: Towards a Governance Approach Working Paper, European Trade Union Institute. Brussels: ETUI.

Canto, V. A., Joines, D. H. and Laffer, A. D. (1983). Foundations of Supply-Side Economics: Theory and Evidence. New York: Academic Press.

Council of Europe (2005). Reconciling Labour Flexibility with Social Cohesion Facing the Challenge, Trends in Social Cohesion No. 15. Strasbourg: Council of Europe Publishing.

Crouch, C. (2006). Capitalist Diversity and Change. Oxford: Oxford University Press. — (2009). 'Privatised Keynesianism: an unacknowledged policy regime'. British Journal of Politics and International Relations, 11: 382-99.

— (2010). 'Flexibility and security on the labour market: an analysis of the governance of inequality'. Zeitschrift für ArbeitsmarktForschung, 43 (1): 17-38.

Davies, P. and Freedland, M. (2007). Towards a Flexible Labour Market: Labour Legislation and Regulation since the 1990s. Oxford: Oxford University Press.

Erne, R. (2008). European Unions: Labor's Quest for a Transnational Democracy. Ithaca, NY: Cornell University Press.

Esping-Andersen, G. (1990). The Three Worlds of Welfare Capitalism. Cambridge: Polity Press.

- (1999). The Social Foundations of Post-Industrial Economies. Oxford: Oxford University Press.

— (2009). The Unfinished Revolution. Cambridge: Polity Press.

European Commission (2005). Working Together for Growth and Jobs. Integrated Guidelines for Growth and Jobs (2005-2008). Luxembourg: Office for Official Publication of the European Communities.

— (2006). Green Book. Luxembourg: Office for Official Publication of the European Communities.

- (2007a). Employment in Europe 2007. Luxembourg: Office for Official Publication of the European Communities. 
(2007b). 'Commission Communication on Flexicurity', MEMO/07/256. Luxembourg: Office for Official Publication of the European Communities.

Ferrera, M. (1996). 'The "southern model" of social Europe'. Journal of European Social Policy, 6 (1): 17-37.

Hay, C., Riihelainen, J. M., Smith, N. J. and Watson, M. (2008). 'Ireland: the outside inside'. In K. Dyson (ed.), The Euro at 10. Oxford: Oxford University Press.

Hollingsworth, J. R. and Boyer, R. (eds) (1997). Contemporary Capitalism: The Embeddedness of Institutions. Cambridge: Cambridge University Press.

—, Müller, K. H. and Hollingsworth, E. J. (2002). Advancing Socio-Economics: An Institutionalist Perspective. Lanham, MD: Rowman and Littlefield.

Jørgensen, H. and Madsen, P. K. (eds) (2007). Flexicurity and Beyond: Finding a New Agenda for the European Social Model. Copenhagen: DJØF Publishing.

Jurado Guerrero, T. and Naldini, M. (1996). 'Is the South so different? Italian and Spanish families in a comparative perspective'. South European Society and Politics, 1 (3): 42-66.

Kenney, M. (ed.) (2000). Understanding Silicon Valley: The Anatomy of an Entrepreneurial Region. Stanford, CA: Stanford University Press.

Klammer, U. and Tillmann, K. (2002). Flexicurity - Soziale Sicherung und Flexibilisierung der Arbeits- und Lebensverhältnisse. Düsseldorf: Ministerium für Arbeit und Soziales, Qualifikation und Technologie des Landes NRW.

Knegt, R. (ed.) (2008). The Employment Contract as an Exclusionary Device. An Analysis on the Basis of 25 Years of Developments in The Netherlands. Antwerp: Intersentia.

Kohli, M. (1999). 'Private and public transfers between generations: linking the family and the state'. European Societies, 1 (1): 81-104.

, Albertini, M. and Künemund, H. (2010). 'Linkage among adult family generations: evidence from comparative survey research'. In P. Heady and M. Kohli (eds), Family, Kinship and State in Contemporary Europe: Volume 3: Perspectives on Theory and Policy. Frankfurt: Campus.

Korpi, W. (1978). The Working Class in Welfare Capitalism: Workers, Unions and Politics in Sweden. London: RKP.

- (1983). The Democratic Class Struggle. London: RKP.

Majone, G. (1990). Deregulation Or Re-Regulation? Regulatory Reform in Europe and the United States. London: Pinter.

Miller, D. (2009). 'Wage determination in outsourced multi-buyer apparel supply chains'. International Journal of Labour Research, 1 (2): 183-200.

Muffels, R., Chung, H., Fouarge, D., Klammer, U., Luijkx, R., Manzoni, A., Thiel, A. and Wilthagen, T. (2008a). Flexibility and Security over the Life Course. Dublin: European Foundation for the Improvement of Working and Living Conditions.

—, Wilthagen, T. and van den Heuvel, N. (eds) (2008b). Flexibility and Employment Security in Europe: Labour Markets in Transition. Cheltenham: Edward Elgar.

Naldini, M. (2003). The Family in the Mediterranean Welfare States. London: Frank Cass.

OECD (1994). The Jobs Study. Paris: OECD.

Olson, M. (1982). The Rise and Decline of Nations. New Haven, CT: Yale University Press.

Roberts, P. C. (1984). The Supply Side Revolution. Cambridge, MA: Harvard University Press.

Rogowski, R. (ed.) (2008). The European Social Model and Transitional Labour Markets: Law and Policy. Aldershot: Ashgate. 


\section{British Journal of Industrial Relations}

Rokkan, S. (1999). State Formation, Nation Building and Mass Politics. Oxford: Oxford University Press.

Rostow, W. W. (1965). The Stages of Economic Growth. Cambridge: Cambridge University Press.

Schmid, G. (2006). 'Social risk management through transitional labour markets'. Socio-Economic Review, 4 (1): 1-32.

- (2008). 'Sharing risks: on social risk management and the governance of labour market transitions'. In R. Rogowski (ed.), The European Social Model and Transitional Labour Markets: Law and Policy. Aldershot: Ashgate, pp. 29-60.

Schneider, F. (2007). 'Shadow economies and corruption all over the world'. Economics, 1: 9.

Shalev, M. (ed.) (1996). The Privatization of Social Policy? Occupational Welfare and the Welfare State in America, Scandinavia and Japan. Basingstoke: Macmillan.

Swenson, P. A. (2002). Capitalists against Markets: The Making of Labor Markets and Welfare States in the United States and Sweden. Oxford: Oxford University Press.

Taylor-Gooby, P. (ed.) (2004). New Risks, New Welfare: The Transformation of the European Welfare State. Oxford: Oxford University Press.

Traxler, F. (2003). 'Bargaining, (de)centralization, macroeconomic performance and control over the employment relationship'. British Journal of Industrial Relations, 41: $1-27$.

, Blaschke, S. and Kittel, B. (2001). National Labour Relations in Internationalized Markets. Oxford: Oxford University Press.

, Brandl, B. and Glassner, V. (2008). 'Pattern bargaining: an investigation into its agency, context and evidence'. British Journal of Industrial Relations, 46 (1): 33-58.

Wilthagen, T. and Tros, F. (2004). " "The concept of 'flexicurity': a new approach to regulating employment and labour markets" in "flexicurity: conceptual issues and political implementation in Europe" '. Transfer, 10 (2): 166-86. 